\title{
Siluetas de Hispanoamericanos
}

\author{
I \\ JOSE ENRIQUE RODO
}

(1917)

\begin{abstract}
GIEMPRE he visto a Rodó estatuario y fijo. Su obra es un vaciado de hombre ilustre; está modelada para sustituir. Su prosa de origen genérico y espíritu libre está bien, siendo particulares sus elementos, en el aire azul. El siglo que él levantó en su América es perdurable por lo limitado. La correspondencia de Grecia, Roma, España y Francia le prestó a Rodó un hermoso fundamento de piedra y él repartió encima sus bloques propios con un orden de templo, de columnata, de promontorio nuevos. Rodó es para mí un paseante de altos niveles clásicos, un peregrino de pie ajustado a solerías inmortales con yerba perenne cariñosa; un huésped permanente de museos, bibliotecas, jardines de eras mejores, abiertos al lento sol único. Por él, que quiso hacer de su Uruguay una sede eterna, vemos su Montevideo como una Atenas, una Florencia, una Salamanca, un París. Porque el hombre tiene tres caras bellas, la cara del amor, la de la oración y la de la poesía, Rodó quiso unir en una estas tres caras.

Una misteriosa actividad nos cogía a algunos jóvenes españoles cuando, hacia 1899, se nombraba en nuestros grupos de Madrid, a Rodó. Aviel, en su único ejemplar conocido,
\end{abstract}


andaba de mano en mano sorprendiéndonos. Qué ilusión entonces para mi deseo poseer aquellos tres libritos delgados, azules, pulcros, de letra nítida roja y negra: Ariel, Rubén Dario, El que vendrá. Después, en 1902, una carta inestimable por mis pobres Rimas enfermas. Luego, para mí solo, sus libros aquellos. Más tarde, en 1908, su Andalucía recóndita por mis ansiosas Elegias. Al fin, Motivos de Proteo, El Mirador de Próspero. Después...

Rojo y oscuro de conjunto, confuso en su acentuación sanguínea, corpulento, vigoroso tronco americano, José Enrique Rodó se levantó brusco y recto en su butaca. Un amigo común nos presentó. Qué sorprendente impresión la mía. Qué ajeno yo, aquella radiante mañana madrileña, de que Rodó estaba "esperándome" en la redacción de España, entonces presidida por José Ortega y Gasset. Qué ajeno de que aquella belleza alta, pura, esmaltada, verdeazul de aquel Madrid de fronda y museo cercanos, rodeaba con magnitud solemne de mausoleo a un hombre que era para ellos necesario $y$ que llevaba ya en su sangre dinámica su permuta definitiva; de que aquel rincón de museo, de botánico, de academia, había enviado ya el mensaje de cesión a sus iguales de Florencia; de que un mar, una tierra atlánticos propios del peregrino se le quedaban a Rodó del todo y para siempre a la espalda.

Qué estúpidamente ajeno yo de que aquel breve encuentro suyo y mío era conocimiento rápido y despedida final; de que aquel transeúnte bueno, fuerte y sano, aquel maestro altivo y generoso, cumpliendo su destino inexorable, iba derecho, por España, a encontrarse en la Italia ideal, camino de Grecia, con la muerte.

II

\section{ALFONSO REYES}

(1933)

Lo conocí en la plataforma de un tranvía amarillo y morado de "Salamanca", Madrid, cruzando la Castellana por la 
Biblioteca. Subía yo adivinándolo y él me sonreía. Sí, su sonrisa, como luego siempre, en su pisito bajo de General Pardiñas, en su piso principal de Serrano, en el Centro de Estudios Históricos, en la Embajada de Méjico, en mi misma casa, me recibió fina, tersa, subida a los ojos. Entonces ¿lo recuerdo bien? Alfonso Reyes usaba un bigotillo mejicano, lacio de curva caída, que armonizaba con los cálidos ojos piliastres y los hoyitos de la mejilla, fuente de su sonrisa. El hombre breve y lleno era entonces todavía, y me parece que lo seguirá siendo, un niño travieso y ya un insigne veterano, en un joven propio. No dos caras distintas, una al pasado y otra al futuro cogidas por la nuca como en lo clásico, sino dos en una y en función general esférica, giratoria, presente, con eje en la medula espinal. Doble, triple ser en instinto, sustancia gris, ansia y fomento de la existencia.

Hombre trino y uno, Alfonso Reyes, superior de espíritu, diferencia, cultura, conciencia, despejo, tolerancia. ¿Desde dónde venía, así preparado de lo ajeno, y de dónde le llegó lo diferente que él mismo le añadía, se incorporaba, se donaba? Tres razas por lo menos sumadas en cuenta final. ¿Cuánto? Su prosa, su verso lo dirán a quien no le conozca de vista. Las siete personalidades, la oblicua, la redonda, la recta, la picuda, la cuadrada, la horizontal, la vertical. Caminos indígenas, españoles, mejicanos hacia lo total permanente. $Y$ todos caminados por lo sumo, con entrega y con análisis, con profundidad y con alegría, con decisión y con serenidad, sin perder de vista nada del tránsito.

Alfonso Reyes, salvador de todo lo salvable. Buen ejemplo y buena amistad la de este sintentizador de Méjico. Dejadores, generosos, llevadores de lo mejor y sin necesidad suplicada del recíproco diario; saboreador el amigo ejemplar de la segura verdad, expresada o secreta. Y un castillo gracioso dondequiera que se pare, y una tienda de campaña, por si acaso, que lo libre cuando anda fuera, en la intemperie mayor. Llega al lugar necesario o gustoso, planta su receptor y su emisor y a dar y a recibir con entusiasmo. Oíalo ahora reír y cantar. Nos tira por el aire caliente o yerto las 
flores y las frutas de donde sea, oeste, norte, este, sur, en la encantadora estación que él hace total.

\section{EUGENIO FLORIT}

Disminuído tras sus lentas gafas grandes, que le adolecen la barbilla, Eugenio Florit me mira con una fina mirada mate de tristeza sonriente. Su sonriente tristeza latina, clásica y futura, lejanísima hacia siempre, es como un efluvio discreto, sustancia de hombre escogido. Lo que aroma el poeta sutil, distraído y secreto, con la destilación tranquila de su pena íntima, se comprende que es el marco espeso (carne, asunto) que los verdaderos poetas tienen siempre alrededor, cárcel del espíritu, para hacerlos ciudadela abierta al espacio. El crisol donde su raíz funde melancolía y saca esencia lo guarda, se ve bien, en lo eterno mejor. $\mathrm{Y}$ así está salvado el hombre en gracia.

Por donde Eugenio Florit venga o vaya, anda por una senda apartada de estatuas y lirios. Exquisito de nacimiento, gris sencillo por suerte para él, está en la estirpe perpetua de la inmanente aristocracia poética y humana: el noble instinto, la buena conciencia, que con su cultivo lo miran y lo entienden todo hermano. Atenta comprensión delicada. Aristocracia que busca aristocrática correspondencia amorosa, religiosa, amistosa, lírica: Laura, Juan de la Cruz, Keats. Y reírse iqué desgracia! de los "hombres".

Eugenio Florit, esbelto tallo universal de español en $\mathrm{Cu}$ ba. Pule su vida y su obra como un ágata serena. Quedará. de él en América y España, por su español perenne, una incorporación ansiosa y aguda. Lengua de pentecostés, espíritu de fuego blanco del alba y de la tarde. Bella fórmula difícil que une al hombre, sin salirlo de su especie, con el rayo de luna, el surtidor y el cisne. Eso es, camino de cisne el suyo (no hay que olvidar que el cisne canta siempre para 
adentro, para sí, y que no muere nunca y no canta para morir; retorcerle el cuello era absurdo).

Sí, Eugenio Florit, poeta aparte, lento en la sombra, cantas para dentro y para arriba y no eres pesado. Es absurdo retorcerte el cuello, cisne intelectivo.

Juan Ramón Jiménez. 
